\title{
SISTEM INFORMASI PENJUALAN BARANG DAN MAINTENANCE PADA PT. V-KOOL INDO LESTARI
}

\author{
Raihan Fadhli' ${ }^{1}$, Nur Alamsyah ${ }^{2}$ \\ ${ }^{1,2}$ Teknik Informatika,Fakultas Teknik dan Ilmu Komputer, Universitas Indraprasta PGRI Jakarta \\ Jalan Raya Tengah, Kelurahan Gedong, Pasar Rebo, Jakarta Timur \\ ${ }^{1}$ raihanfadhli8@gmail.com,$\underline{2}$ alamcbr11@gmail.com
}

\begin{abstract}
ABSTRAK
Penulis melakukan riset tentang sistem informasi di PT V-Kool dan menemukan bahwa perusahaan masih menggunakan aplikasi Microsoft Excel sebagai program aplikasi untuk membantu menyimpan dan menghitung data, sehingga masih memiliki beberapa kelemahan, salah satunya adalah proses penyimpanan data yang terbatas sehingga banyak data yang tercampur dan sulit untuk dicari. Tujuan dari penelitian adalah untuk menganalisis penggunaan sistem yang digunakan perusahaan untuk pencatatan penjualan dan maintenance. Metode penelitian yang digunakan untuk merancang pengelolaan sistem adalah metode grounded research. Selanjutnya, penulis menggunakan metode wawancara, dan kepustakaan untuk mendapatkan data lebih lengkap. Penelitian menggunakan beberapa objek yang ditelitinya. Adapun teknik penyusunanya adalah Analisis Kebutuhan Sistem, Studi Kepustakaan/Studi Literatur, Pengumpulan Data dan Perancangan Sistem, Pengkodean Sistem dan Pengujian Sistem. Kesimpulan dari hasil penelitian ini adalah aplikasi atau program yang telah dirancang oleh peneliti dapat digunakan oleh perusahaan untuk mengubah proses pencatatan manual dan transfer informasi yang sebelumnya Microsoft Excel menjadi sistem yang lebih praktis, efisien dan terintegrasi. Proses pencatatan informasi perusahaan juga menjadi lebih aman dikarenakan program dirancang dengan sistem login yang tidak bisa dilakukan oleh sembarang pihak, sehingga informasi perusahaan lebih aman dan terjaga. Proses sistem informasi menjadi efisien dan akurat serta penyajian laporan yang lebih terkoordinasi sesuai kebutuhan yang diinginkan.
\end{abstract}

Kata Kunci: Aplikasi Maintenance, Java Netbeans.

\begin{abstract}
Researchers conducted research on information systems at PT V-Kool and found that the company still uses the Microsoft Excel application as an application program to help store and calculate data, so it still has several weaknesses, one of which is the limited data storage process so that a lot of data is mixed and hard to find. The purpose of this study is to analyze the use of the system used by the company for recording sales and maintenance. The research method used to design the system management is the grounded research method. Furthermore, the author uses the interview method, and literature to obtain more complete data. The research uses several objects under study. The preparation techniques are System Requirements Analysis, Literature Study / Literature Study, Data Collection and System Design, System Coding and System Testing. The conclusion from the results is that the application or program that has been designed by the researcher can be used by companies to change the manual recording and information transfer process that was previously Microsoft Excel into a more practical, efficient and integrated system. The process of recording company information is also safer because the program is designed with a login system that cannot be done by just anyone, so that company information is safer and more secure. The information system process becomes efficient and accurate and the presentation of reports is more coordinated according to the desired needs.
\end{abstract}

Key Word: Maintenance Application, Java Netbeans.

\section{PENDAHULUAN}

Informasi teknologi merupakan pengetahuan yang berkembang pesat dan cepat pada masa globalisasi, saat ini penggunaan alat bantu komputer sebagai salah satu sarana penunjang dalam segala aspek kebutuhan pekerjaan yang dapat meningkatkan kinerja dan mempermudah proses pekerjaan terutama dalam hal yang membutuhkan ketepatan dan kecepatan dalam penggunaan data, salah satunya digunakan untuk mengontrol persediaan barang suatu perusahaan.

Menurut (Handoko, 2015) menjelaskan bahwa persediaan (inventory) adalah suatu istilah umum yang menunjukan segala sesuatu atau sumber daya-sumber daya organisasi yang disimpan dalam antisipasinya terhadap pemenuhan permintaan. Pengertian persediaan menurut (Suharli dan Rachpriliani, 2006) adalah barang yang 
dibeli untuk dijual lagi sebagai aktivitas utama perusahaan untuk memperoleh pendapatan. Menurut (Warren, 2005) persediaan barang adalah barang dagang yang disimpan untuk kemudian dijual dalam operasi bisnis perusahaan dan bahan yang digunakan dalam proses produksi atau yang disimpan untuk tujuan itu.

Dari teori ini penulis menyimpulkan persediaan merupakan suatu sumber daya perusahaan yang dapat disimpan untuk mengantisipasi adanya permintaan yang tinggi dari konsumen.

PT V-Kool Indo Lestari pertama kali didirikan di Indonesia pada tahun 1995 yang merupakan distributor eksklusif dari merk kaca film ternama. Kantor pertama PT V-Kool berlokasi di Karang Anyar, Jakarta Pusat. Dalam perkembangannya, PT V-Kool mulai melebarkan sayapnya dengan membuka jaringan dealer, pelatihan teknisi dan perekrutan hingga menjadi pemimpin pasar. Namun, pesatnya perkembangan bisnis PT VKool saat ini, sistem pengelolaan dan penyajian data masih menggunakan program sederhana berupa Microsoft Excel sebagai program aplikasi untuk membantu menyimpan dan menghitung data. Sehingga penggunaan aplikasi Microsoft Excel tersebut masih memiliki beberapa kelemahan salah satunya adalah proses penyimpanan data yang terbatas sehingga banyak data yang tercampur dan sulit untuk dicari. Sedangkan proses mencari data penjualan dituntut dengan cepat untuk melakukan proses-proses lainnya seperti pembayaran dan pelunasan.

Berdasarkan pemaparan masalah di atas, diperlukan adanya suatu sistem yang terintegrasi untuk mengatasi masalah tersebut. Sistem merupakan sesuatu yang terdiri dari objek, unsur atau komponen yang saling berkaitan dan berhubungan satu sama lain, sehingga objek-objek tersebut menjadi pengolahan tertentu atau satu kesatuan pemrosesan. Moekijat dalam (Prasojo, 2011). Menurut (Mustakini, 2009), sistem dapat diartikan melalui pendekatan komponen dan pendekatan prosedur. Dalam pendekatan prosedur, sistem merupakan kumpulan dari prosedur dengan tujuan tertentu. Pengertian sistem menurut (Romney dan Steinbart 2015) merupakan rangkaian dari dua atau lebih komponen yang saling berhubungan, yang berinteraksi untuk mencapai suatu tujuan. Sebagian besar sistem terdiri dari subsistem yang lebih kecil yang mendukung sistem yang lebih besar. Kemudian, definisi sistem menurut (Mulyadi, 2016) sistem adalah suatu jaringan prosedur yang dibuat menurut pola yang terpadu untuk melaksanakan kegiatan pokok perusahaan.

Berdasarkan teori-teori tentang sistem dari para ahli di atas, penulis dapat menarik kesimpulan bahwa sistem merupakan sekumpulan elemen-elemen yang saling berinteraksi untuk suatu tujuan tertentu.

Dengan begitu, berdasarkan latar belakang yang telah dikemukakan oleh penulis di atas, maka rumusan masalah pada penelitian ini adalah bagaimana merancang program sistem informasi yang bisa memberikan kemudahan kepada pihak perusahaan meliputi efektivitas, dan efisiensi dalam pendataan transaksi penjualan. Aplikasi ini dapat digunakan untuk mempermudah pekerjaan staff ataupun admin perusahaan dalam melaksanakan pembuatan laporan dan mempercepat dalam proses data pencarian data laporan penjualan.

\section{METODE PENELITIAN}

Metode penelitian adalah metode yang digunakan untuk mengetahui hasil dari penelitian dengan cara mengumpulkan, mencatat dan menganalisa informasi data yang ada. Penelitian dilakukan di PT V-Kool Indo Lestari, beralamat di Jakarta Pusat yang dilaksanakan sejak bulan Maret 2021 sampai dengan Juli 2021.

Penelitian ini menggunakan teknik grounded (grounded research), yaitu suatu teknik penelitian yang didasarkan pada fakta, menggunakan analisis perbandingan untuk tujuan menetapkan konsep, mengadakan generasi empiris, membuktikan dan mengembangkan teori, mengumpulkan dan menganalisa data dalam waktu yang bersamaan (Nazir, 1988). Menurut (Moleong, 2007), Grounded Theory merupakan proses bertahap yang cukup rumit. Penelitian dilakukan memunculkan pertanyaanpertanyaan generatif yang membantu penelitian namun tidak dimaksudkan untuk tetap statis atau menjadi dinamis. Pendekatan grounded theory menurut (Noor, 2017) adalah 
untuk menghasilkan atau menemukan suatu teori yang berhubungan dengan situasi tertentu. Inti dari pendekatan grounded theory ialah pengembangan suatu teori yang berhubungan erat kepada konteks peristiwa yang dipelajari.

Dalam riset ini, data menjadi sumber teori. Langkah-langkah yang digunakan pada teknik ini yaitu menentukan masalah yang ingin diteliti, mengumpulkan data dan informasi yang terdapat di lapangan, analisis dan memaparkan masalah yang ditemukan, serta membuat laporan hasil penelitian. Berdasarkan teori di atas, bahwa grounded research adalah metode penelitian kualitatif yang mencoba merekonstruksi teori atas suatu fakta yang ada di lapangan berdasarkan data melalui analisis induktif.

Dalam metode pengumpulan data, penulis menggunakan beberapa metode yaitu wawancara dan sesi tanya jawab dengan pengurus dan beberapa karyawan perusahaan, observasi dengan langsung terjun ke lapangan, dan studi pustaka dengan membaca atau menganalisis catatan, arsip, dokumen, serta teori literatur dari penelitian sebelumnya.

Untuk langkah-langkah pengembangan sistem, penulis melakukan beberapa aktivitas yaitu:

1. Menganalisa kebutuhan sistem dilakukan pengumpulan kebutuhan dengan berfokus pada perangkat lunak, meliputi: informasi, fungsi masing-masing pada bagian sistem, kerja atau cara kerja dan antarmuka. Lalu menyediakan perangkat Diagram Alir Data (DAD) dan teknik yang dapat membantu menulis untuk menentukan kebutuhan melalui sistem yang telah berjalan pada sistem dalam melakukan pengolahan data.

2. Setelah semua data yang dibutuhkan sudah didapat, maka penulis melakukan perancangan struktur data, arsitektur perangkat lunak, dan rincian karakteristik antarmuka.

3. Kemudian merancang tampilan layar seperti form masukan dan form keluaran. Selanjutnya peneliti melakukan pengkodean sistem dari semua data yang telah didapat ke dalam sebuah bahasa pemrograman dan di implementasikan ke dalam sebuah aplikasi.
4. Sebelum sistem aplikasi dokumentasi dapat digunakan dengan baik, harus dilakukan pengujian terlebih dahulu. Rangkaian pengujian ini dijalankan bersama-sama dengan data aktual dari sistem yang sudah ada atau sistem yang sedang berjalan

\section{HASIL DAN PEMBAHASAN Analisa Permasalahan}

Dari latar belakang yang telah dijelaskan, penulis mengidentifikasikan permasalah pada penelitian ini sebagai berikut:

1. Sistem pendataan penjualan perusahaan masih menggunakan sistem sederhana dan manual yaitu Microsoft Excel 2016, sehingga dalam segi pengolahan data menyita waktu yang relatif lama.

2. Penyimpanan data yang masih manual, dimana pasti memiliki kelemahan yaitu daya tampung record yang kurang maksimal sehingga membatasi data yang dimasukkan.

3. Pembuatan laporan administrasi penjualan masih menggunakan sistem manual, sehingga administrator perlu merekap kembali satu persatu data yang sudah dimasukkan sebelumnya.

4. Proses pendataan maupun pencarian informasi menjadi tidak efisien dan efektif.

\section{Alternatif Penyelesaian Masalah}

Dalam mencari solusi atas permasalahan perusahaan, penulis mengembangkan suatu program yang akan memudahkan dalam menyelesaikan kendala tersebut. Berdasarkan analisis sistem yang sudah berjalan, penulis menemukan beberapa kelemahan yang terdapat pada sistem informasi laporan data kegiatan penjualan, sehingga penulis memberikan beberapa saran alternatif untuk menyelesaikan masalah, diantaranya:

1. Perancangan sistem informasi berbasis desktop yang diharapkan bisa memberikan informasi yang tepat, cepat serta akurat.

2. Data kegiatan maintenance yang bisa disimpan dalam bentuk database sehingga memudahkan dalam mengolah data tersebut.

3. Merancang aplikasi sistem maintenance agar informasi yang akan dibutuhkan ataupun didapatkan dapat dengan mudah dimengerti oleh pengguna sehingga dengan mudah digunakan oleh 
manajemen, baik yang mengerti maupun yang tidak mengerti komputerisasi.

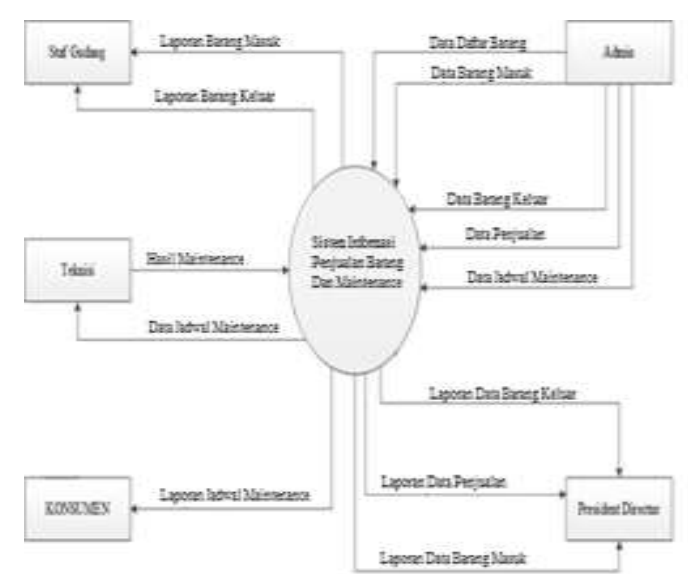

Gambar 1. Diagram Konteks

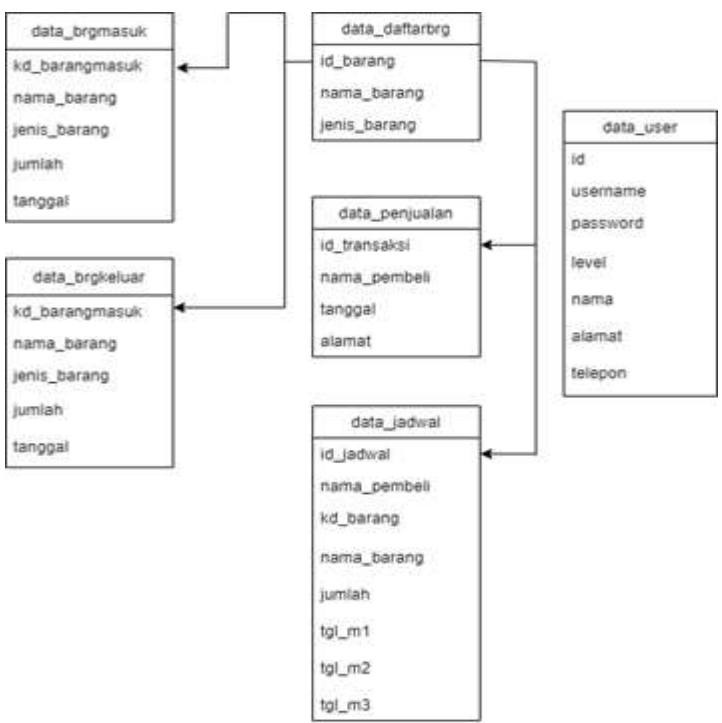

Gambar 2. Normalisasi

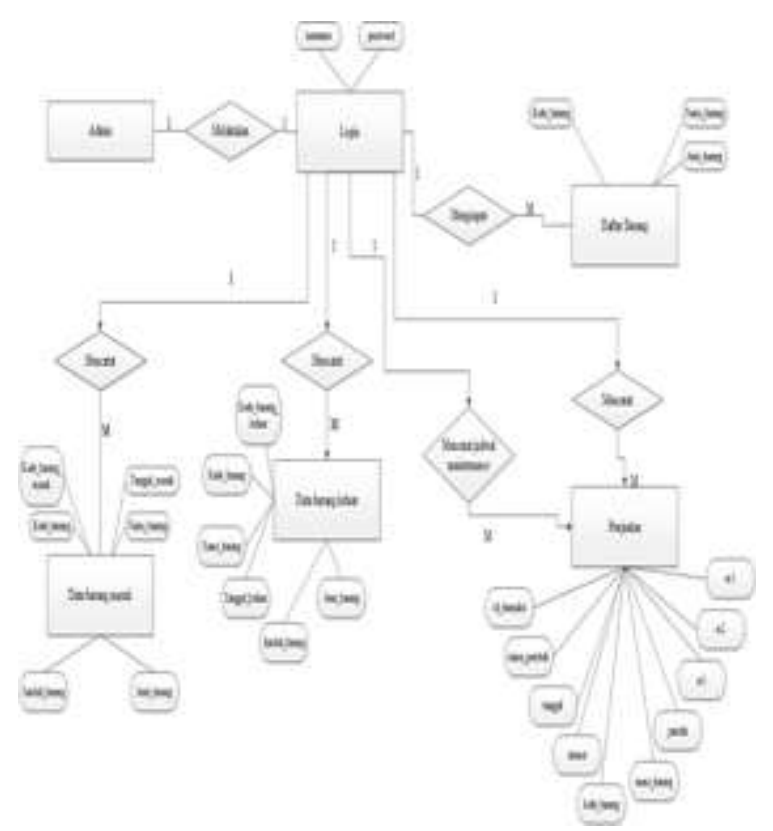

Gambar 3. ERD (Entity Relationship Diagram)
Berikut ini adalah hasil pengujian software program dan tampilan layar yang telah dibuat dengan sistem pemrograman Java Netbeans.

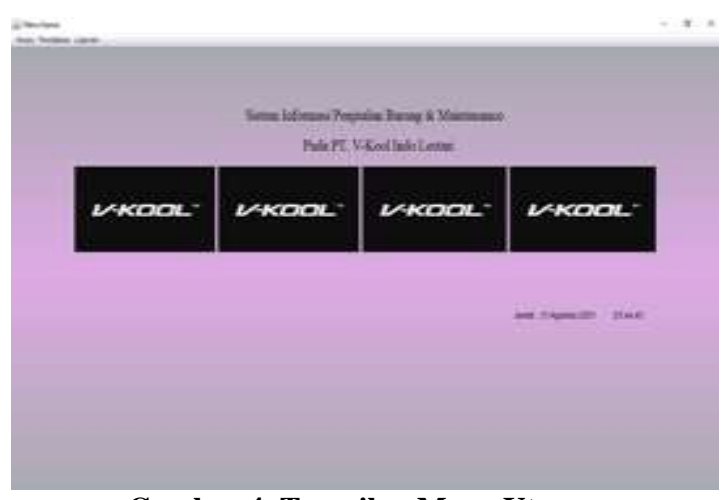

Gambar 4. Tampilan Menu Utama

Layar di atas menampilkan tampilan Menu Utama pada Sistem Informasi Penjualan Pada PT V-Kool Indo Lestari berbasis Java NetBeans. Pada layar utama tersedia menu bar yang terdiri dari master data yang digunakan untuk memasukkan data yang terkait dengan data penjualan, data barang, data garansi barang, dan laporan-laporan.

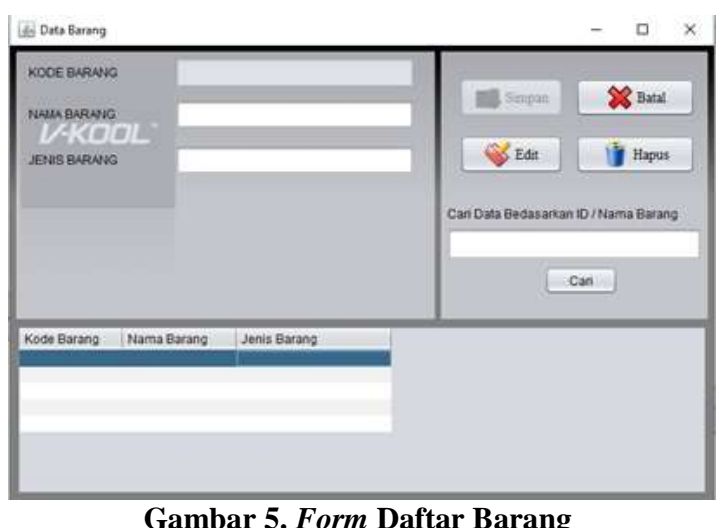

Tampilan ini merupakan tampilan daftar barang, menu ini dapat dipakai untuk pencatatan data barang perusahaan.

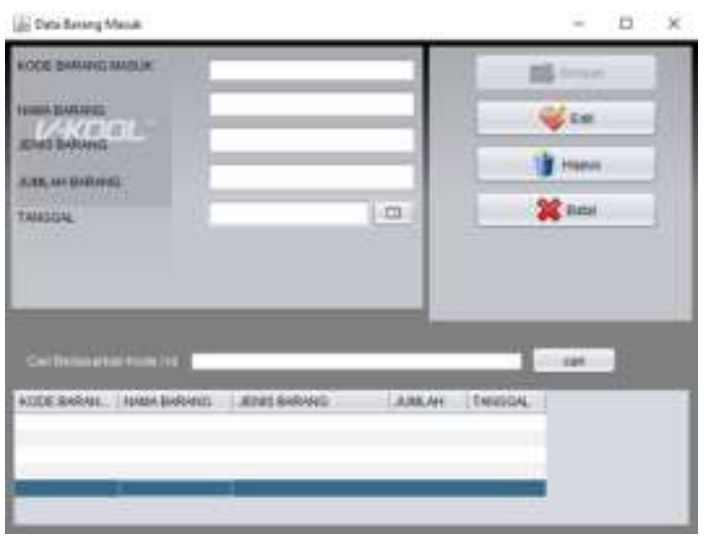

Gambar 6. Form Data Barang Masuk

1220 | Sistem Informasi Penjualan Barang dan Maintenance pada PT. V-Kool Indo Lestari 
Tampilan ini merupakan tampilan layar data barang masuk yang ada dalam sistem penjualan pada PT V-Kool Indo Lestari.

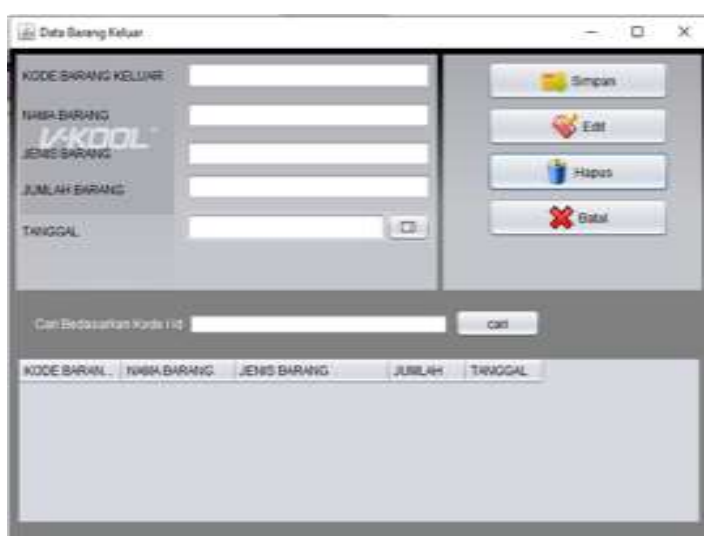

Gambar 7. Data Form Data Barang Keluar

Tampilan ini merupakan tampilan layar data barang keluar yang ada dalam sistem penjualan pada PT V-Kool Indo Lestari.

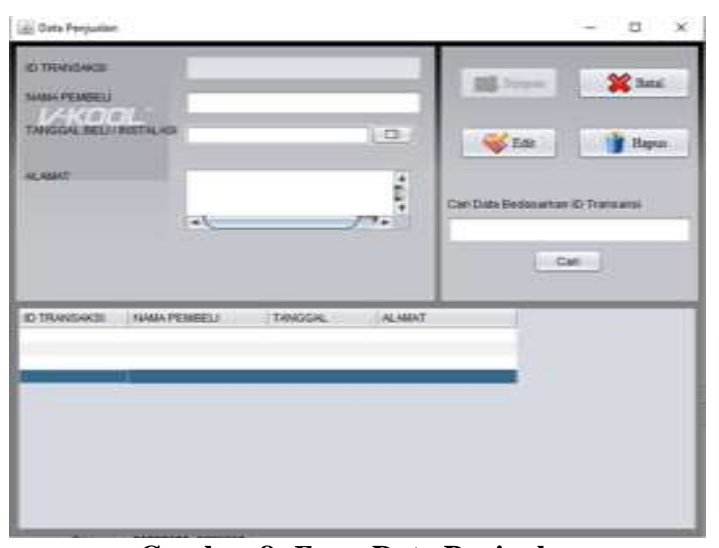

Gambar 8. Form Data Penjualan

Merupakan tampilan data penjualan yang dibuka di PT. V-Kool Indo Lestari, menu ini digunakan untuk pengecekan, pencatatan dan updating data penjualan

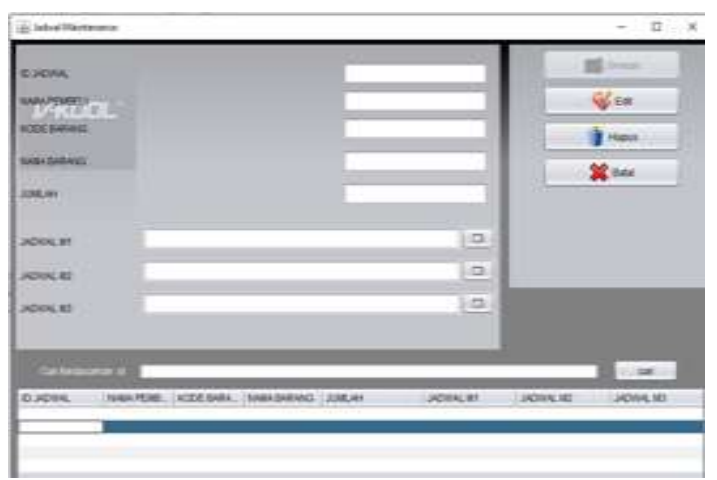

Gambar 9. Form Data Jadwal Maintenance

Merupakan tampilan data jadwal maintenance yang dibuka di PT. V-Kool Indo Lestari, menu ini digunakan untuk pengecekan, pencatatan dan updating data jadwal maintenance.

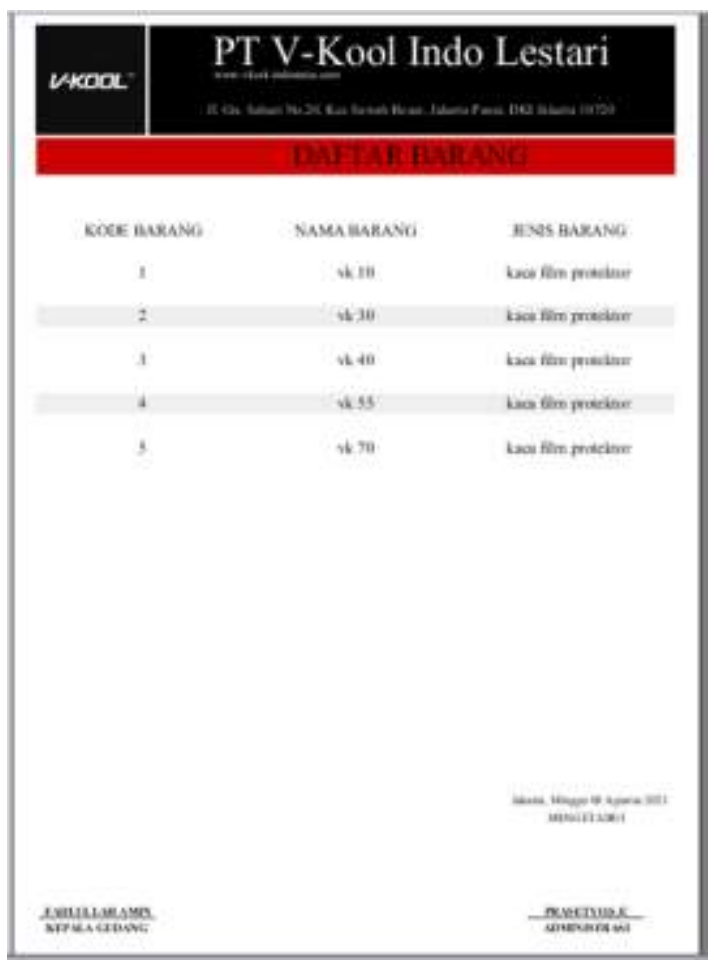

Gambar 10. Laporan Daftar Barang

Dalam laporan daftar barang terdapat informasi tentang seluruh data barang yang ada di PT V-Kool Indo Lestari.

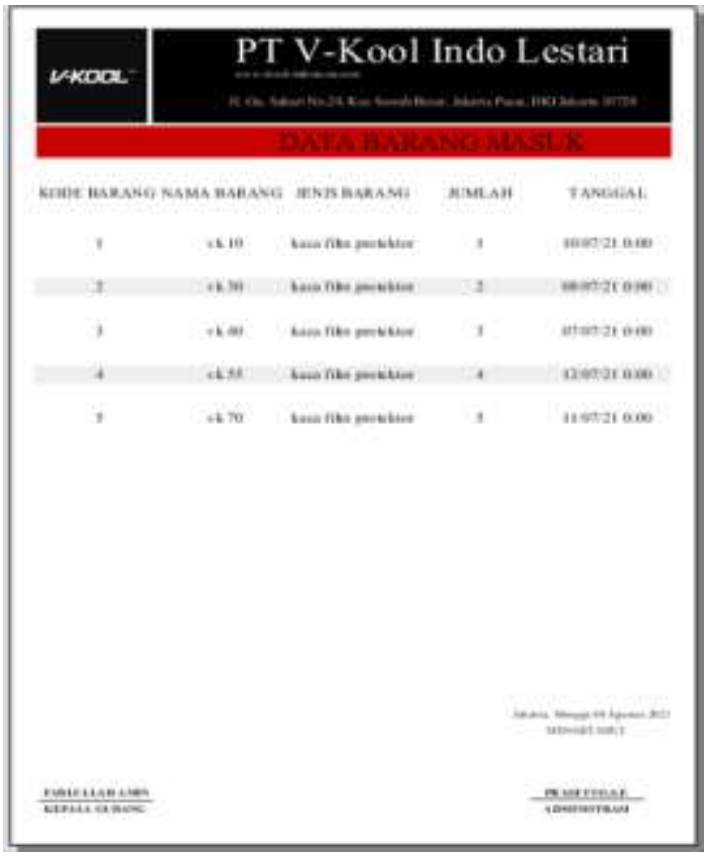

Gambar 11. Laporan Data Barang Masuk

Dalam laporan data barang yang masuk terdapat informasi tentang data barang yang baru masuk. 


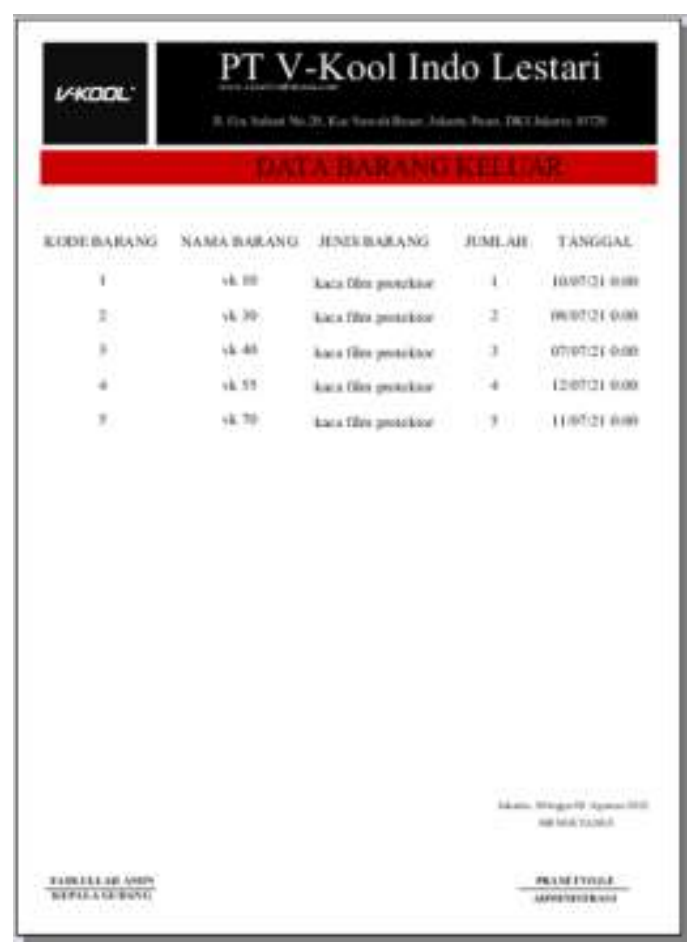

Gambar 12. Laporan Data Barang Keluar

Dalam Laporan data barang keluar terdapat informasi tentang data barang keluar.

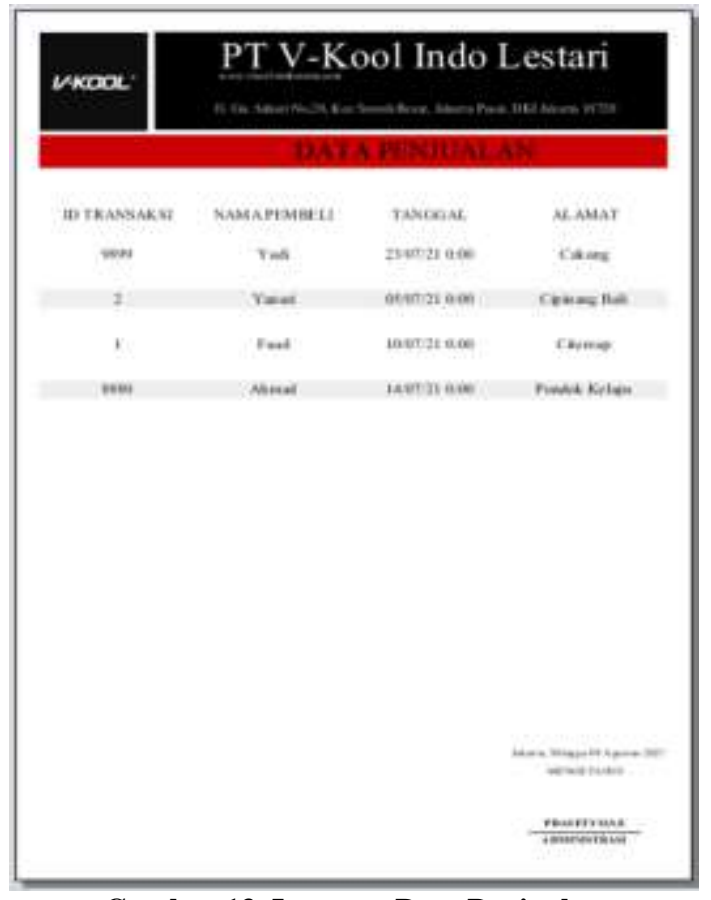

Gambar 13. Laporan Data Penjualan

Laporan data penjualan berisi data penjualan perbulan atau pertahun PT V-Kool Indo Lestari.

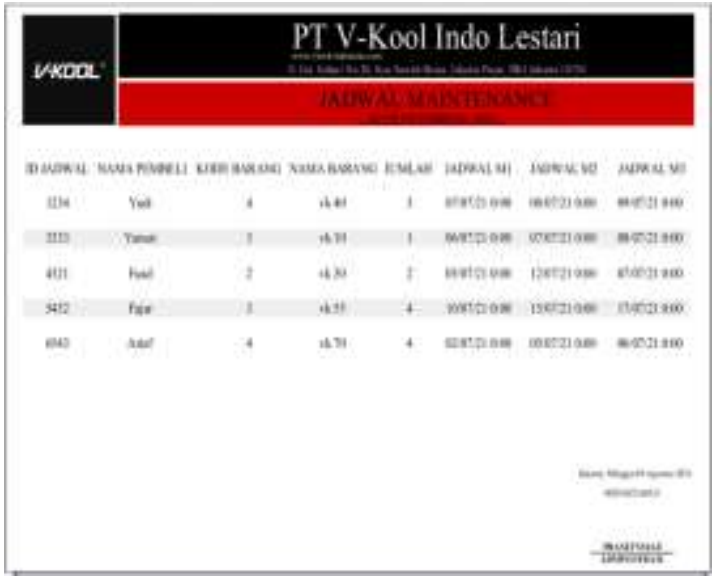

Gambar 14. Laporan Data Pembeli dan Jadwal Maintenance

Dalam laporan data pembeli/ jadwal maintenance yang berisikan tentang jadwal maintenance dan data pembeli seperti kartu garansi

\section{SIMPULAN DAN SARAN}

Program yang dibuat dapat digunakan dengan baik dan mampu untuk menggantikan proses pencatatan manual dan transfer informasi yang sebelumnya hanya menggunakan Microsoft Excel. Penggunaan program tidak dapat dilakukan oleh sembarang orang karena dilengkapi dengan sistem login. Proses sistem informasi menjadi lebih akurat dan efisien serta penyajian laporan yang lebih terkoordinasi sesuai kebutuhan yang diinginkan.

Saran penulis yaitu dalam pengembangan berikutnya, diharapkan sistem ini tidak hanya mampu melakukan penyajian sistem informasi maintenance tetapi juga mampu melakukan pencatatan proses administrasi keuangan. Pada tahapan pengembangan selanjutnya, dapat ditambahkan beberapa prosedur enkripsi data yang berfungsi untuk meningkatkan sistem keamanan program pada aplikasi. Melakukan pelatihan pada admin perusahaan agar dapat memahami fungsi dan menggunakan aplikasi ini.

\section{DAFTAR PUSTAKA}

Handoko, T.Hani. 2015. Dasar-Dasar Manajemen Produksi dan Operasi. Edisi Pertama. BPFE-Yogyakarta

Moleong, Lexy J. 2007. Metodologi Penelitian Kualitatif. Edisi Revisi. Bandung: PT Remaja Rosdakarya.

Moekijat. Prasojo. (2011). Pengantar Sistem 
Informasi Manajemen. Bandung: CV.

Remadja Karya.

Mulyadi. (2016). Sistem Informasi Akuntansi. Jakarta: Salemba Empat.

Mustakini, Jogiyanto Hartono. (2009). Sistem Informasi Teknologi. Yogyakarta: Andi Offset.

Nazir, M. 1988. Metode Penelitian. Jakarta: Ghalia Indonesia.

Noor, Juliansyah. 2017. Metode Penelitian. Jakarta: Cetakan Ketujuh. Kencana.

Romney, Marshall B. dan Steinbart, (2015), "Sistem Informasi Akuntansi", Edisi 13, alih bahasa: Kikin Sakinah Nur Safira dan Novita Puspasari. Jakarta: Salemba Empat.

Suharli dan Rachpriliani. (2006). Studi Empiris Faktor-Faktor Yang Berpengaruh Terhadap Ketepatan Waktu Pelaporan Keuangan, Jurnal Bisnis dan Akuntansi, Vol 8 No. 1.

Warren Reeve Fess. (2005). "Accounting/ Pengantar Akuntansi". 21 th edition. Jakarta: Salemba Empat. 